\title{
Influencia del metacaolín en la estructura porosa de matrices a base de mc/cemento
}

\author{
Influence of the metakaolin on porous structure of matrixes \\ based in $\mathrm{mk} /$ cement
}

Fecha de aceptación: 6-11-99

M. FRIASYM.I.SÁNCHEZ de ROJAS

Instituto de Ciencias de la Construcción Eduardo Torroja (CSIC)

Fecha de aceptación: 17-02-00

ESPAÑA

\section{RESUMEN}

La incorporación de materiales puzolánicos presenta un efecto positivo en la mejora de las prestaciones de los morteros y hormigones mixtos. Estos modifican la estructura porosa, impidiendo o retrasando el acceso de los medios agresivos y, por lo tanto, contribución a la obtención de materiales mixtos más durables.

La mayor o menor durabilidad de las pastas, morteros y hormigones mixtos dependerá de la composición quimica, mineralógica, finura y de la cinética de reacción de estas adiciones activas.

En el presente trabajo se recogen los resultados de una investigación llevada a cabo para conocer el efecto de un material activado (metacaolin) en la microporosidad de pastas, elaboradas con diferentes contenidos de metacaolin (mc) (0-25\%). Se utilizó una relación agua/ material cementante de 0,55 y fueron curadas a $20^{\circ} \mathrm{C}$ para periodos de hidratación desde 1 dia hasta 360 dias.

La evolución de la porosidad total, capilar, gel y el tamaño de poro medio se determinó mediante la técnica de porosimetria de mercurio (PIM). También, el picnómetro de Helio se utilizo como método alternativo, para obtener información de la porosidad superior a $1,4 \stackrel{\circ}{A}$.

Se obtuvo una buena correlación entre ambos métodos $y$, por otro lado, se propone el contenido más idóneo de $m k$ para la elaboración de pastas mixtas.

\section{SUMMARY}

The incorporation of pozzolanic materials in the manufacturing of blended cement has a positive effect on the improvement of blended mortar and concretes performances. These active additions modify porous structure, impeding or delaying the access of aggressive solutions and, therefore materiais more durable are possible of obtaining.

An increase or decrease on the durability of blended pastes, mortars and concretes will depend on chemical and mineralogical compositions, fineness and reaction kinetics of these pozzolans.

The current work shows the results of a research carried out in blended pastes to know the effect of activated material (metakaolin) on the microporosity of pastes elaborated with different amounts of $m k(0-25 \%)$. A water/ binder ratio of 0,55 was used. Samples were cured at $20{ }^{\circ} \mathrm{C}$ for 360 days.

The evolution of total, capilary and gel porosity as well as average pore size were carried out through mercury intrusion porosimeter (MIP). Also, the helium pycnometer as alternative method to obtain additional information about porosity above $1,4 \stackrel{\circ}{A}$ was used.

A good correlation between both methods has been obtained. In addition, it is proposed the best mk content for the elaboration of mk-blended pastes. 


\section{INTRODUCCIÓN}

El cemento portland es el material más utilizado en el sector de la construcción, por las ventajas que ofrece frente a otros materiales. La resistencia ha sido una de las características asociada a los morteros u hormigones desde el inicio de su empleo. Sin embargo, debido al aumento creciente de los agentes agresivos, los materiales a base de cemento muestran una falta de durabilidad, principalmente en los hormigones armados.

A lo largo del tiempo, las condiciones para conseguir una adecuada durabilidad está evolucionando, desde un aumento de las cantidades de cemento, pasando por la utilización de aceros sin mantenimiento, hasta reducir considerablemente la relación agua/cemento, dando lugar a una nueva generación de hormigones, llamados de alta y muy altas prestaciones (1). A pesar de estas soluciones, no se podría concebir un hormigón durable a medio o largo plazo sin la incorporación de adiciones activas.

El uso de adiciones para la elaboración de morteros y hormigones incluye generalmente puzolanas naturales de origen volcánico y subproductos industriales como ceniza volante y humo de sílice, principalmente.

En la mayoría de los casos, los morteros y hormigones conteniendo materiales con características puzolánicas tienen porosidades iguales o superiores al mortero $u$ hormigón de referencia (2). A pesar de esto, es importante señalar que, en todos los casos, se produce un refinamiento de la estructura porosa capilar, dando lugar a una red de poro más tortuosa, impidiendo o retrasando el acceso de los medios agresivos, los cuales producirán un deterioro de los materiales conglomerantes a través de diferentes mecanismos. Este hecho, producirá un mejoramiento de las prestaciones y, más concretamente, de la durabilidad (3-4).

En los países en desarrollo, regiones tropicales y subtropicales, su economía y su desarrollo tecnológico limitan la producción y uso de cemento con subproductos industriales, debido a la escasa disponibilidad de estos materiales. Sin embargo, materiales naturales como la caolinita son abundantes.

En los últimos años, un nuevo material está siendo investigado por sus altas propiedades puzolánicas (5-11) En trabajos anteriores (12-13), los autores del presente trabajo indicaron que el mc mostraba un comportamiento más cercano al humo de sílice que a la ceniza volante, debido a su finura, composición química y actividad puzolánica. Este comportamiento del mc tendrá su repercusión en la microestructura, especialmente en la estructura porosa. Los tamaños de poro junto al diámetro de poro medio son buenos indicadores de las características de la estructura porosa.

\section{INTRODUCTION}

Portland cement is a material widely used in construction because of its advantages with respect to another materials. The strength has been one of the characteristics associated with mortars and concretes since the beginning of its use. However, in presence of aggressive agents, cement based materials show a lack of durability, mainly, in reinforced concretes.

During the current century, the conditions for getting concretes with accepted durability have been changing, from a increase of cement amounts, more durable steels to a considerably decrease of water/ cement ratio, giving a new concretes generation called high and very high performances (1). In spite of these solutions, it is not possible to elaborate more durable concrete without the incorporation of actives additions.

The use of mineral additions for the manufacture of mortars and concretes generally include natural pozzolans from volcanic origin, artificial ones like fly ashes and silica fume, mainly.

In most of the cases, mortars and concretes containing material with pozzolanic characteristics have porosity values equal or superior to that $O P C$ concrete (2). In spite of that, it is important to note that in all cases, they experiment a refineness in their capillary porous structure, giving place to more tortuous pore nets, impeding or delaying the access of aggressive media that will produce a decay of conglomerate materials through different mechanism (3-4)

In most developing countries within the tropical subtropical regions, economic and technological constraints limit the production and use of cement with artificial pozzolans due to the no availability of these by-products. However, natural materials like thermally activated kaolinite are readily available.

Last years, a new material (metakaolin) is being studied because of its high pozzolanic properties (5-11). In previous papers (12-13), the authors of current paper reported that mk showed a closer behaviour to silica fume than to fly ash, owing to its fineness, chemical composition and pozzolanic activity. This different behaviour of the $m k$, will have its repercussion on microstructure, specially on pore structure. The pore size distribution in conjunction with the average pore diameter is good indicator of pore structure characteristics. 
Este trabajo recoge los resultados de un estudio detallado en la porosidad total, porosidades parciales y diámetros de poro medio, llevados a cabo en pastas con $0,10,15,20$ y $25 \%$ de mc. Las pastas fueron curadas a $20^{\circ} \mathrm{C}$ durante un año.

La porosimetría de intrusión de mercurio (PIM) se usó para conocer la influencia del $\mathrm{mc}$ en el refinamiento de los tamaños de poro y, por otro lado, también se llevó a cabo un estudio de la porosidad mediante el uso del picnómetro de helio, el cual permite conocer la evolución de la porosidad por encima de $1,4 \AA$.

Es objetivo de esta investigación recomendar la cantidad óptima de mc para la elaboración de cementos mixtos más duraderos.

\section{PARTE EXPERIMENTAL}

\subsection{Materiales}

Para este estudio se utilizó metakaolin y cemento portland blanco comerciales disponibles en el Reino Unido. Sus composiciones y algunas de sus propiedades fisicas se recogen en las Figuras 1 y 2 .

Se prepararon 5 mezclas diferentes, en las que el cemento portland era sustituido por $0,10,15,20 \mathrm{y}$ $25 \%$ de metacaolin.

La relación agua/material cementante fue de 0,55 en peso. Las mezclas se colocaron en recipientes de plásticos herméticos y curados en una cámara de curado a $100 \%$ H.R. Después de 1, 3, 7, 28, 56, 90 , 180 y 360 días de curados, las muestras se introdujeron en una estufa de vacío durante 3 días a $50^{\circ} \mathrm{C}$ de temperatura y 1 bar, con el objetivo de parar el progreso de la reacción de hidratación sin alterar las fases hidratadas.

\subsection{Técnicas de ensayo}

La caracterización de la estructura porosa de las pastas mixtas se llevó a cabo mediante la técnica de la porosimetría de mercurio, Micromeritics Autopore 9200, capaz de medir diámetros de poro hasta $30 \AA$.

También, la porosidad total puede ser calculada por el método propuesto por Cabrera (14), conociendo el contenido de humedad, densidad húmeda, densidad seca y densidad real de la muestra. Esta densidad real se determinó mediante la técnica del Picnómetro de Helio, Auto Pycnometer 1320, la cual permite conocer la porosidad total por encima de 1,4 $\mathrm{A}$.
This study reports the results of a detailed study on total and partial porosities and average pore diameter carried out in pastes with 0,10,15,20 and $25 \%$ of $\mathrm{mk}$, cured at $20^{\circ} \mathrm{C}$ and for periods up to one year.

Mercury intrusion porosimetry (MIP) was used to know the influence of $m k$ on the refineness of pore sizes. Also, a study on total porosity using the helium picnometer that permits to know the evolution of porosity above $1.4 \stackrel{A}{ }$ was carried out. The results obtained by both methods are discussed and compared.

From this study, the optimal amount of mk in the elaboration of blended pastes will be recommended.

\section{PART EXPERIMENTAL}

\subsection{Materials}

For this study, a commercial metakaolin and white cement available in England was used. Their chemical compositions and some physical properties are shown in Figures 1 and 2.

Five different mixes were prepared in which cement was partially replaced by $0,10,15,20$ y 25\% of metakaolin.

Water/binder ratio was 0,55 in weight. The samples were introduced in airtight plastic container and maintained in cured room at 100 R.H. for 1, 3, 7, 28, 56, 90,180 and 360 days; subsequently, they were put in a vacuum oven for 3 days at $50{ }^{\circ} \mathrm{C}$ and $1 \mathrm{bar}$, in order to stop the hydration reaction process.

\subsection{Testing techniques}

The porosity (total and partials) and the average pore diameter was measured by mercury porosimeter, Micromeritics Autopore 9200, which it is able to measure poro diameter up to $30 \AA$.

Also, total porosity can be calculated by the Cabre$\mathrm{ra}^{\prime}$ method (14), knowing the humidity content, wet density, dry density and real density of sample. The real density was calculated by Helium Picnómeter, Auto Pycnometer 1320, which can measure poro diameter up to $1.4 \stackrel{\leftrightarrow}{A}$. 


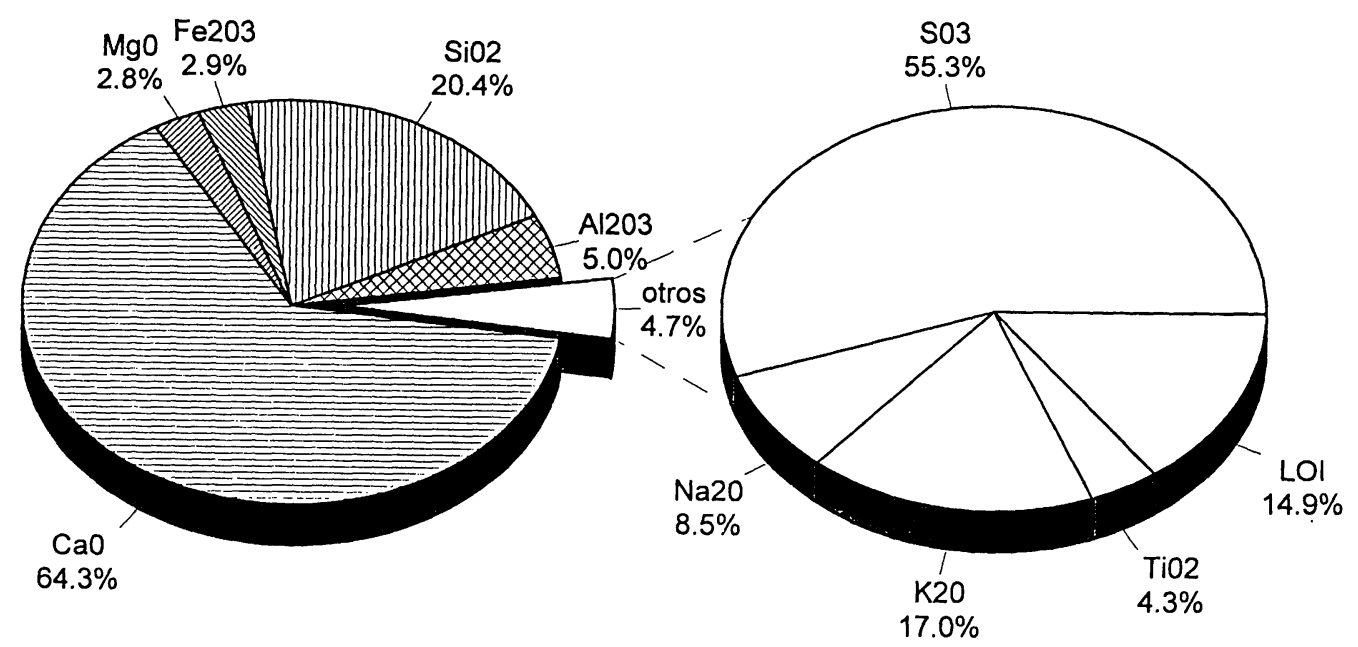

Densidad relativg $\left(\mathrm{g} / \mathrm{cm}^{3}\right)=3.27$

Rel. density $\left(\mathrm{g} / \mathrm{cm}^{3}\right)=3.27$

Área superficial $\left(\mathrm{m}^{2} / \mathrm{g}\right)=1.1$

Surface area $\left(\mathrm{m}^{2} / \mathrm{g}\right)=1.1$

Figura 1.- Composición quimica del cemento.

Figure 1.- Chemical composition of cement.

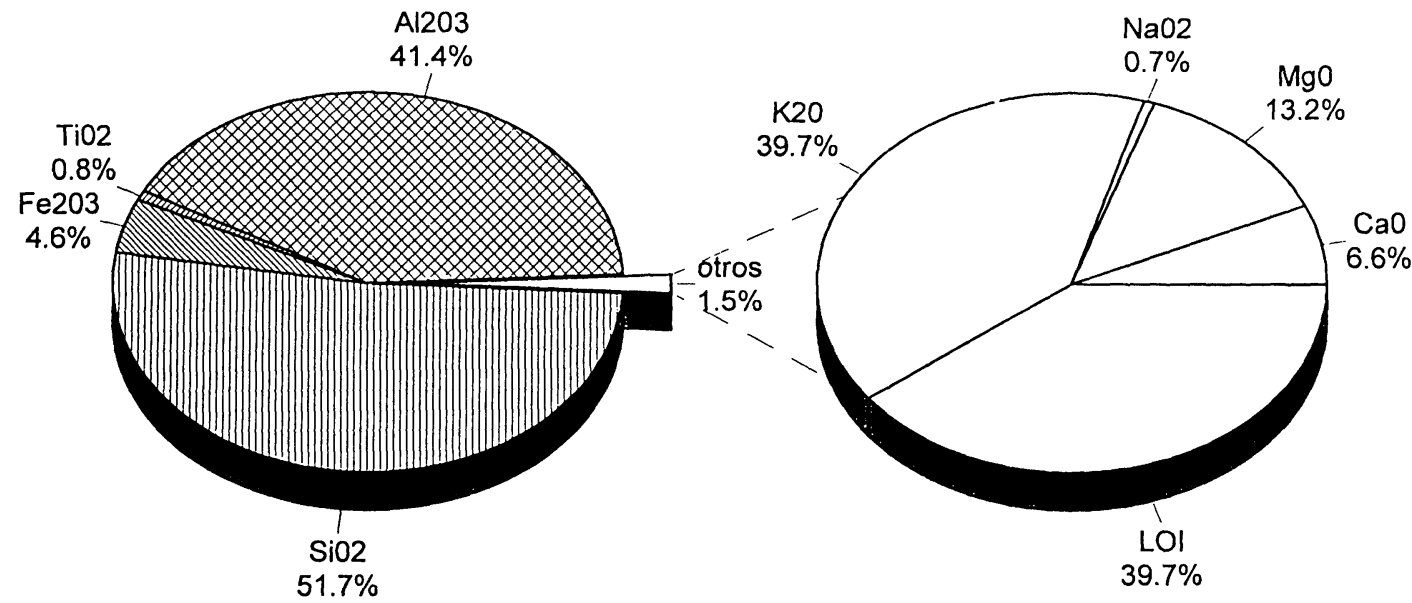

Densidad relativa $\left(\mathrm{g} / \mathrm{cm}^{3}\right)=2.7$

Área superficial $\left(\mathrm{m}^{2} / \mathrm{g}\right)=15$

Surface area $\left(m^{2} g\right)=15$

Figura 2.- Composición quimica del metacaolín.

Figure 2.- Chemical composition of metakaolin.

\section{RESULTADOS Y DISCUSIÓN}

\subsection{Caracterización de la estructura porosa por} porosimetría de mercurio

La evolución de la porosidad total, capilar y de gel para las diferentes muestras ensayadas con el tiempo de curado, se representan en la Figura 3.

\section{RESULTS AND DISCUSION}

\subsection{Characterisation of porous} structure by MIP

The evolutions of total, capillary and gel porosity are represented in Figure 3. 

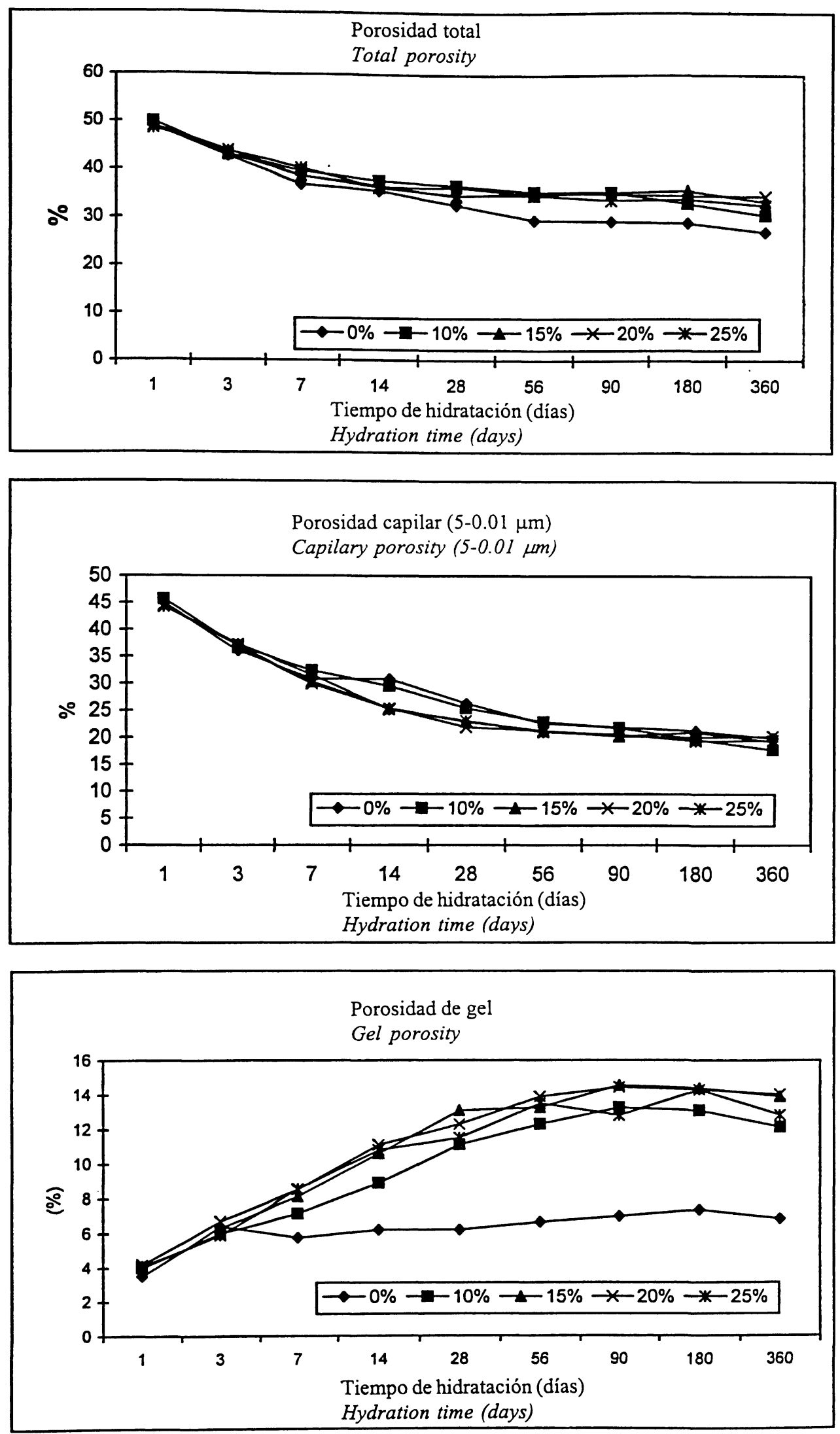

Figura 3.- Evolución de las porosidades con el tiempo de hidratación.

Figure 3.- Evolution of porosity with the hydration time. 
La porosidad total disminuye con el tiempo de hidratación, detectándose una reducción desde el 50\% hasta el $30 \%$. A primeras edades (1 y 3 días), las porosidades totales son muy similares, independientemente del contenido de mc. A partir de 7 días de hidratación, la pasta de referencia muestra una mayor disminución que las pastas elaboradas con mc. Al final del ensayo, había una reducción de la porosidad total del $40 \%$; mientras que las pastas con diferentes contenidos de mc (10,15, 20 y $25 \%)$ experimentaban una reducción de la porosidad sólo del $30 \%$.

Este hecho pone de manifiesto que la presencia de mc aumenta la porosidad total con respecto a una pasta de referencia. Sin embargo, este aumento de la porosidad no está claramente relacionado con su contenido (entre 10 y $25 \%$ ).

En cuanto a la porosidad capilar, la misma tendencia se encontró durante los primeros días (hasta 7 días); sin embargo, entre 7 y 90 días de curado se detectó que la porosidad capilar es tanto mayor cuanto menor es el contenido de mc en las pastas. La porosidad capilar se reduce considerablemente cuando los contenidos de mc superan el 10\%. Para períodos de hidratación superiores a 90 días, las porosidades capilares encontradas fueron muy similares.

El efecto positivo de la incorporación del mk en la estructura porosa de pastas mixtas está relacionado con el refinamiento de los tamaños de poro, por debajo de $100 \AA$. Un aumento gradual en los poros de geles se observa con el curado. Las pastas con mk muestran un $60 \%$ más de poros de geles que la pasta de referencia. Al igual que ocurría con la porosidad capilar, el refinamiento de los tamaños de poro era más importante en las pastas con altos contenidos de mc $(15-25 \%)$.

Una evidencia clara de la influencia del mc en el refinamiento de los tamaños de poro puede ser cuantificada mediante el diámetro de poro medio. La Figura 4 recoge la evolución de este parámetro con el tiempo.

Una fuerte reducción en el diámetro de poro medio se observa en todas las pastas durante los primeros días de curado. A partir de 14 días, se encuentra las mayores diferencias entre la pasta de referencia y las pastas mixtas.

Las pastas sin mc mostraban una reducción desde $40 \mathrm{~nm}$ a $15 \mathrm{~nm}$; mientras que en las pastas con altos contenidos de mc (15-25\%) se reducía desde $33 \mathrm{~nm}$ a $10 \mathrm{~nm}$. La pasta con un $10 \%$ de mc presentaba una reducción intermedia a los casos anteriores.
Total porosity decreased with curing time, detecting a reduction from 50\% to 30\%. At first ages (1 and 3 days), total porosities were very similar, not existing any relation with mk content. From 7 days of hydration, the reference paste showed a higher decrease, compared with that mk-blended pastes. Once test finished, there was a decrease of total porosity of about $40 \%$; while the pastes with different mk contents $(10,15,20$ y 25\%) only showed a reduction of porosity of $30 \%$.

This fact shows that the presence of $m k$ increases the total porosity with respect to the control paste. However, this phenomenon is not clearly related with its content (between 10 and 25\%).

With respect to the capillary porosity, the same trend during the first days (up to 7 days) was found; however, it was detected that capillary porosity increased when mk content decreased. Therefore, capillary porosity was considerably reduced with $\mathrm{mk}$ content above $10 \%$. For longer hydration periods of 90 days, capillary porosities were very similar.

The positive effect of the incorporation of mk on porous structure is related with the refineness of pore sizes under $100 \stackrel{A}{A}$. A gradual increase of the gel pores with curing time was observed. Pastes with mk showed a $60 \%$ of gel pores higher than those of control paste. As it happened with capillary porosity, the refineness of pore sizes was more important in pastes with high mk contents (15-25\%).

The clear evidence of the influence of mk on the refineness of pore sizes can be calculated through the average pore diameter. Figure 4 shows the evolution of this parameter with time.

An important reduction on the average pore diameter was observed in all pastes during the first days of curing. Beyond 14 days, a greater difference between control paste and mk-blended pastes was found.

Control paste showed a reduction of the average pore size from $40 \mathrm{~nm}$ to $15 \mathrm{~nm}$; while the blended pastes with high mk contents (15-25\%) reduced from $33 \mathrm{~nm}$ to $10 \mathrm{~nm}$. Paste with $10 \%$ of mk showed an intermediate behaviour with respect to the cases mentioned before. 


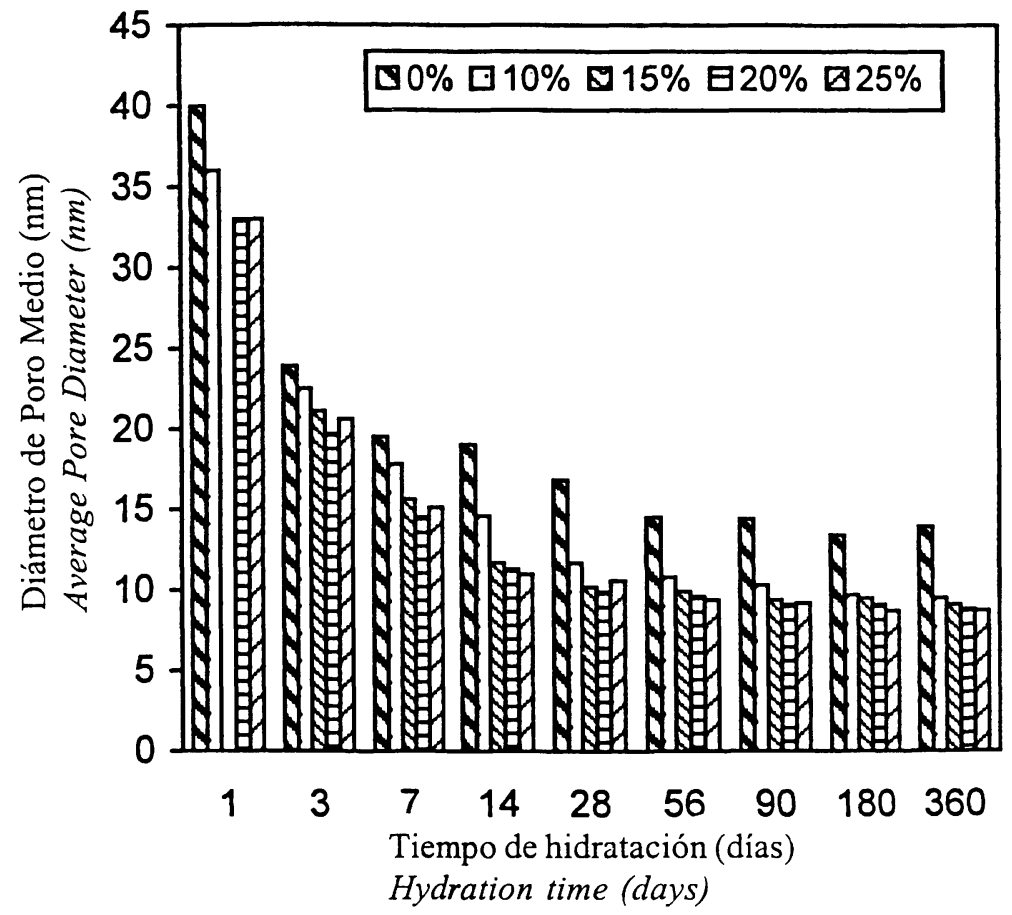

Figura 4.- Evolución del diámetro de poro medio con el ticmpo de hidratación.

Figure 4.- Evolution of average pore diameter with the hydration time.

Estas observaciones están de acuerdo con los resultados obtenidos por Khatib and Wild (15). Ellos reportaron este mismo fenómeno en pastas con contenidos de mc hasta $15 \%$.

No hay dudas de las observaciones hechas que un aumento de los contenidos de mc en las muestras producen un refinamiento de la estructura porosa. Los mejores resultados son obtenidos con contenidos igual o superior a $15 \%$ de mc.

\subsection{Determinación de la porosidad por Picnómetro de Helio}

El porosímetro de mercurio es un método normalmente usado para estudiar la porosidad y la estructura de poro de materiales basados en cemento. Sin embargo, los resultados del MIP pueden estar afectados por el método de muestreo, condiciones de ensayo, masa, tamaño y dimensión de la muestra, velocidad de ensayo, ángulo de contacto y tensión superficial del mercurio, etc. (16).

Por esta razón, la porosidad de una muestra era también calculada siguiendo el método propuesto por Cabrera (14). Brevemente, el método consiste en la medida de la densidad húmeda de la pasta, corrigiendo el contenido de humedad y calculando la densidad relativa mediante el Picnómetro de Helio.
These findings are in agreement with the results obtained by Khatib and Wild (15). They reported this phenomenon in pastes with mk contents up to $15 \%$.

From the observations mentioned here, there are no doubts that an increasing mk contents produces a refineness in the porous structure. The best results were obtained with mk contents equal or superior to $15 \%$.

\subsection{Determination of porosity by Helium Picnometer}

Mercury intrusion porosimeter (MIP) is a popular method for studying porosity and pore structure of cement based materials. However, the MIP results can be affected by the method of sampling, sample conditioning, sample mass and dimension used, the rate of pressure application, values of contact and surface tension of mercury assumed, etc. (16).

For this reason, the porosity of a specimen was also calculated following the method proposed by Cabrera (14). Briefly it consists of the measurement of the wet density of the paste, correcting for moisture content and calculating the relative density by Helium Picnometer. 
La Figura 5 muestra la evolución de los valores de la densidad relativa con el tiempo. En todos los casos, se observaba una fuerte reducción de la densidad relativa durante los primeros días de hidratación (hasta 7 días). Por encima de esta edad, las pastas con mc mostraban un comportamiento diferente a la pasta de referencia. Entre 7 y 28 días, las pastas con diferentes contenidos de mc mostraban una disminución de la densidad relativa desde 2,4 a 2,2 g/c.c. Posteriormente, los valores fueron prácticamente constantes. Finalmente, las pastas con mk experimentaban una ligera disminución por encima de 180 días, alcanzando un valor de $2,05 \mathrm{~g} / \mathrm{c} . \mathrm{c}$.

En el caso de la pasta de referencia, el valor de la densidad relativa no mostraba cambios importantes después de 7 días de curado. Un valor de 2,16 g/c.c. se obtenía después de 360 días.

La porosidad total de las pastas usando el Picnómetro de Helio y los valores de la porosidad obtenido por MIP dieron resultados comparables. Los valores obtenidos por MIP fueron ligeramente más bajos que los obtenidos por helio (Figura 6).

Este hecho es debido porque el gas helio es capaz de acceder a los poros más pequeños, donde el mercurio no puede hacerlo.
The evolution of the relative density values with time is shown in Figure 5. A strong reduction on the relative density is observed in the first days of hydration in all cases (up to 7 days). Above this period, the mk-pastes showed a different behaviour with respect to the control paste. Between 7-28 days, pastes with different $m k$ contents showed a decrease of relative density from 2.4 to $2.2 \mathrm{~g} / \mathrm{c}$.c. Subsequently, values were practically constant. Finally, they experimented a slight decrease above 180 days, reaching a value of about 2,05 g/c.c.

In the case of control paste, it is clearly observed that the value of the relative density does not show any important change after 7 days of curing. A value of 2,16 g/c.c. was detected after 360 days of hydration.

The total porosity of the pastes measured using Helium Picnometer and the total porosity values obtained through mercury intrusion porosimetry gave comparable results. The values obtained by MIP were slightly lower than those by helium (Figure 6).

This is probably because the helium gas is able to gain access into most of the finer pores, where the larger molecules of mercury can not enter.

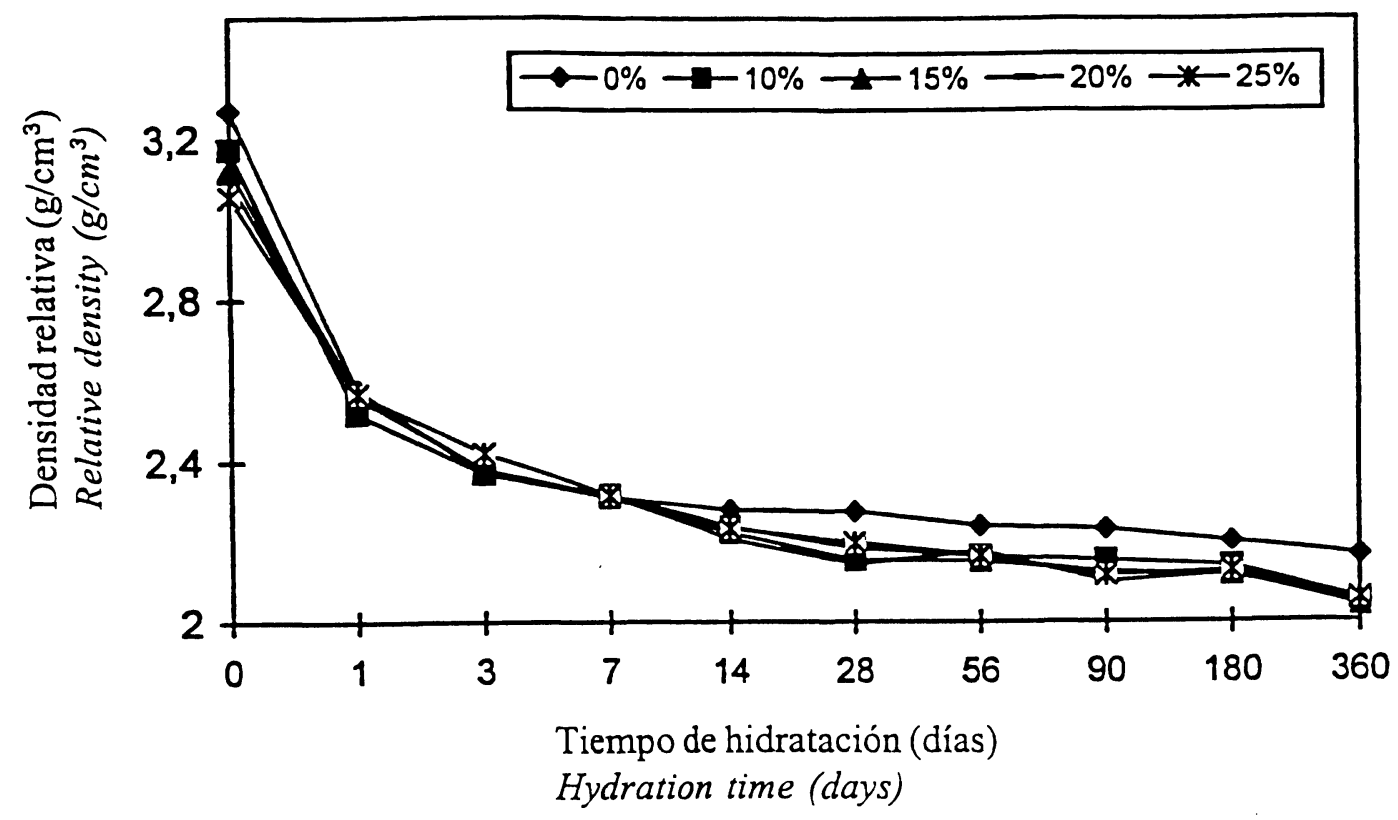

Figura 5.- Evolución de la densidad real con el tiempo de hidratación.

Figure 5.- Evolution of relative density with the hydration time. 

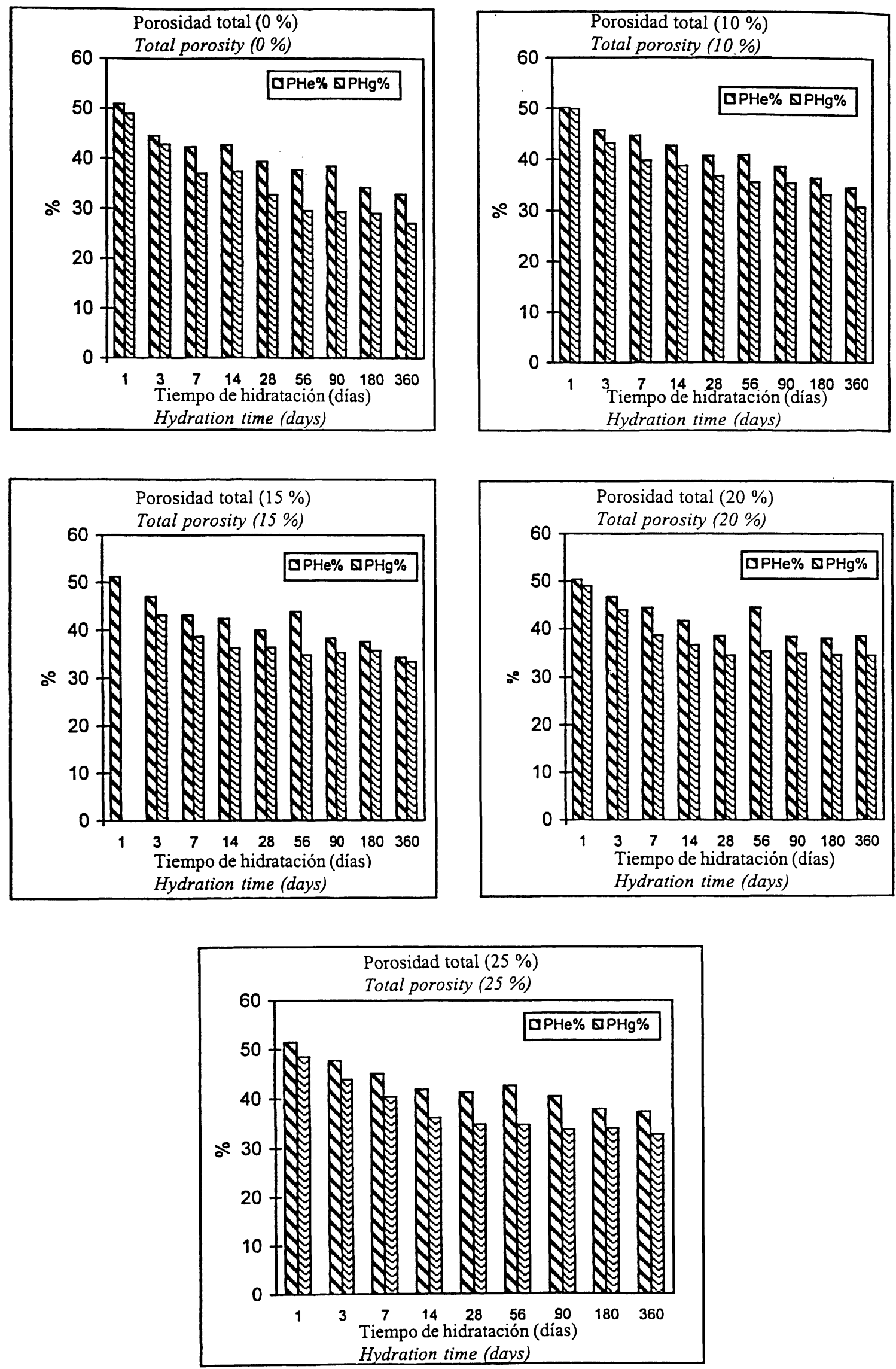

Figura 6.- Estudio comparativo de las porosidades totales obtenidas por ambos métodos

Figure 6.- Comparative study of total porosities between both methods. 
La relación estadística $\left(R^{2}=0,86\right)$ entre ambas porosidades, dio la siguiente ecuación (Figura 7):
The statistical relation $\left(R^{2}=0,86\right)$ between both porosities (Figure 7) gave the following equation:

$$
\mathrm{P}_{\mathrm{Hg}}=1,072 \mathrm{P}_{\mathrm{He}}-7,4205
$$

donde: $\mathrm{P}_{\mathrm{Hg}}=$ Porosidad de intrusión de mercurio (\%) y $\mathrm{P}_{\mathrm{He}}=$ Porosimetría de helio (\%)

where: $P_{\mathrm{Hg}}=$ Mercury intrusion porosity (\%) and $P_{\mathrm{He}}=$ Helium porosity (\%)

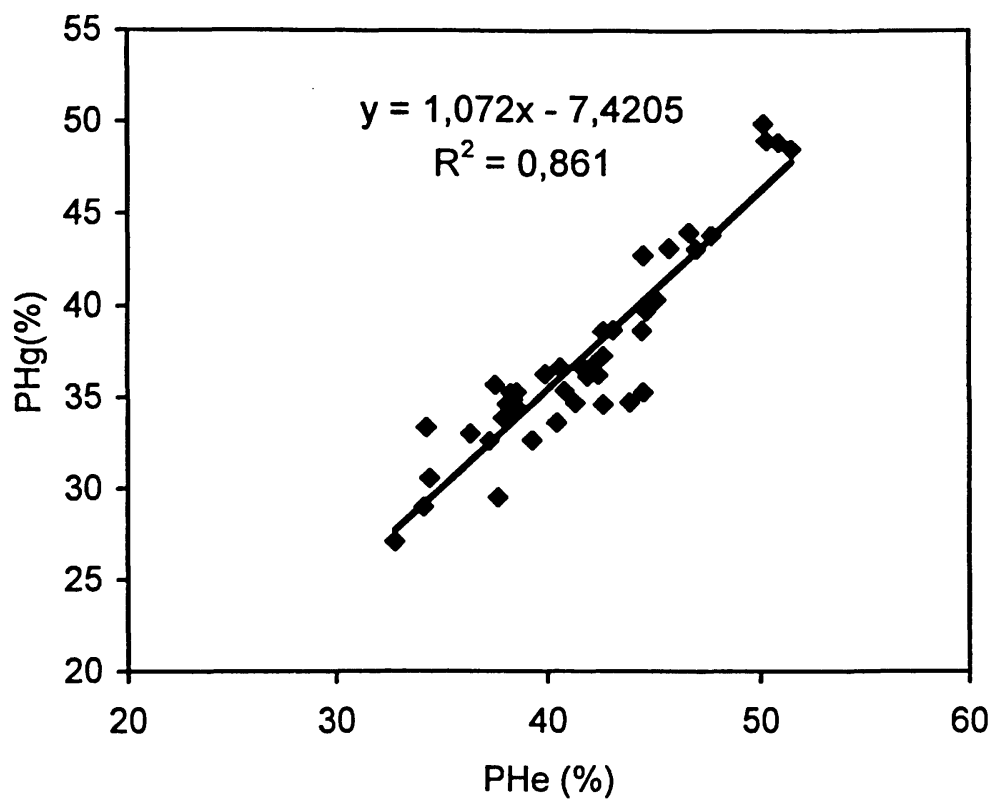

Figura 7.- Relación entre ambas porosidades.

Figure 7.- Relation between both porosities.

\section{CONCLUSIONES}

Las siguientes conclusiones pueden ser obtenidas de la presente investigación:

- 1. La incorporación de mc en la elaboración de cementos mixtos, provoca un aumento de la porosidad total por encima de los tres días de hidratación.

\section{La porosidad capilar experimenta un} comportamiento diferente. Las pastas con mc $(>10 \%$ de $\mathrm{mc}$ ) presentaban porosidades capilares más bajos que la pasta de referencia, entre 7 y 90 días de curado.

3. La influencia positiva del mc en los cementos mixtos está claramente demostrada en el refinamiento de la estructura porosa, por debajo de $100 \AA$ A. de tamaño de poro. A 90 días de curado, la porosidad de gel en las pastas con mc es 2,3 veces superior que la pasta de referencia.

\section{CONCLUSIONS}

From the current work, the following conclusions can be obtained:

1. The incorporation of $m k$ in elaboration of blended pastes produced an increase of the total porosity at curing time longer than 3 days.

2. The capillary porosity experiments on different behaviour. Pastes with $\mathrm{mk}(>10 \%$ of $\mathrm{mk}$ ) showed lower capillary porosity than that of the control paste, mainly, between 7 and 90 days of curing.

3. The positive influence of the $m k$ in blended pastes is clearly demonstrated on the refineness of the porous structure, mainly, below $100 \ddot{A}$ of poro size. At 90 days, the gel porosity was 2.3 times higher than that of the control paste. 
4. La proporción de poros con diámetro de poro medio más bajos de $10 \mathrm{~nm}$ se incrementa con la incorporación de mc.

5. No hay duda de las observaciones mencionadas anteriormente, la recomendación de añadir un mínimo del $15 \%$ de mc para obtener pastas con una importante microporosidad de gel. Este hecho tendrá una incidencia directa en una mayor durabilidad frente a los agentes agresivos.

6. Una buena correlación se ha encontrado entre los dos métodos utilizados para conocer la porosidad de las pastas. La caracterización de la porosidad mediante la densidad relativa (Picnómetro de $\mathrm{He}$ ) permite determinar tamaños de poro superiores a $1,4 \AA$.

7. De acuerdo con los resultados expuestos aquí, no sólo es importante conocer la porosidad total, sino que también es necesario conocer otros parámetros como: porosidad capilar y porosidad de gel y principalmente, el diámetro de poro medio para describir o diseñar materiales con adecuadas prestaciones a medio y largo plazo.

\section{AGRADECIMIENTO}

Los autores agradecen a la beca Marie Curie Grant (TMR), la cual financió esta investigación.
4. The pores proportion with average pore diameter smaller than 10nm is increased with the incorporation of $M K$.

5. From the results mentioned before, it is possible to recommend a minimum of $15 \%$ of $\mathrm{mk}$ in the elaboration of $m k$-blended pastes, with the objective of obtaining pastes with an important microporosity of gel. This fact, it will have direct repercussions in its durability against aggressive elements.

6. A good correlation between both porosity methods was found. The characterisation of the porosity through relative density (Helium Picnometer) permits to know pore sizes above $1.4 \stackrel{\circ}{A}$.

7. According to the results obtained here, not only the total porosity is important but it is also important to know another parameters, such as: capillary porosity, gel porosity and average pore diameter to describe or design materials with high performances at short and long term as well.

\section{ACKNOWLEDGMENT}

The authors want to thanks to the Marie Curie Grant (TMR), which supported the current research.

\section{BIBLIOGRAFÍA}

(1) Andrade C., Frías, M. y Marina M.A. (1995). "Hormigones de altas prestaciones. Hormigones más durables”. Estratos, n 35, Primavera, 18-23.

(2) Frías, M. and Sánchez de Rojas M.I. (1997). "Microstructural alterations in fly ash mortars:study on phenomena affecting particle and pore size". Cement and Concrete Research, 27, $n^{\circ} 4,619-628$.

(3) Khatib J.M. and Wild S.(1996). "Pore size distribution of mk paste". Cement and Concrete Research, 26, n⿳ 10, 1545-1553.

(4) Talero, R.:"Contribución al estudio analí y fisico-químico del sistema: cementos puzolánicos-yeso-agua". Tesis Doctoral. Universidad Complutense de Madrid. Ftad de C. Químicas, 1986, Madrid.

(5) Silva P.S., Glasser F.P.(1993) "Phase relation in the system CaO-Al2O3-SiO2-H2O relevant to mk-lime hydration", Cem. Concr. Res, 23,627-639.

(6) Ambroise J., Maximilien S. and Pera P. (1994). "Properties of MK blended cement”, Adv Cem Bas Mat (1) (1994) 161-168

(7) Coleman N.J. and Page C.L. (1997). "Aspects of the pore solution chemistry of hydrated cement pates containing MK", Cem Concr Res., 27(1) 147-154.

(8) Wild S., Khabit J.M.and Jones A. (1996) "Relative strength pozzolanic activity and cement hydration in superplisticised mk concrete", Cem. Concr. Res., 26(10)1537-1544.

(9) Bai J., Wild S., Sabir B.B. and Kinuthin J.M. (1999). "Workability of concrete in incorporating PFA and mk". Magazine of Concrete Research, 51 (3) 207-226.

(10) Mejia, R. “Contribución al estudio analítico y físico-químico del sistema: cementos portland, puzolanas y escorias siderurgícas, cloruros y agua". Tesis Doctoral. Universidad Complutense de Madrid. Ftad de C. Químicas, 1997, Madrid.

(11) Talero, R, Bollati, R, Hernández, F. (1999): " Preparación de morteros y hormigones no tradicionales a base de cementos portland, metacaolin y yeso", Materiales de Construcción, $n^{\circ} 49(256) 29-41$.

(12) Frías M., Sánchez de Rojas M.I. and Cabrera J.G. (2000). "The effect that the pozzolanic reaction of mk has on the heat evolution in mk-cement mortar”, Cem. Concr. Res., 30 (2) 209-216.

(13) Cabrera J.G. and Frías M. (2000). “Mechanism of hydration of the mk-lime-water system”, Cem. Concr. Res., accepted.

(14) Cabrera J.G. (1985) "The porosity of concrete".Con. Soc. Res. Sem, Leeds. UK

(15) Khabit J.M and Wild S.(1996). "Pore size distribution of Mk". Cem. Concr. Res., 26(10), 1545-1553.

(16) Laskar, M.A.I., Kumar, R. And Bhattacharjee (1997): “ Some aspects of evolution of concrete through mercury intrusion pororosimetry", Cem. Concr. Res., 27(1) 93-105. 